et's do a little experiment. Before you read the rest of this article, go to your reference desk (or information desk, or help desk, or whatever term you use for your primary, in-person service point). Look around. What do you see? Are there people in the area? Are they staff or users? What are they doing? What library materials are they reading or using? What personal materials are they reading or using? Are they alone or in groups? Is it noisy or silent?

By some accounts, what you should be witnessing is a silent, dusty, empty warehouse with rows of books in perfect order, waiting for the odd chance that someone will come in to use one of them. The computers might be in use, but only for e-mail or basic Web surfing. Because the library is an irrelevant, technological backwater, there is little demand for even this aspect of library service. The reference librarian sits waiting for that one scholar who still uses print resources to come in and ask for help. The circulation staff spends their time rearranging the books on the shelves-the library equivalent of rearranging the deck chairs on the Titanic. And everyone reminisces about the "good old days" when people actually used the library.

My guess is that this is not at all the image that you see

David A. Tyckoson, 2007-2008 President of the Reference and User Services Association, is Associate Dean, Henry Madden Library, California State University, Fresno; e-mail:davety@ csufresno.edu. (unless the library is closed when you are conducting the experiment). When I go to a library-and especially a public library-I see lots of people doing lots of different things. Rather than a silent and empty reading room, the reference area is crowded and noisy. It echoes with the sound of conversations, keyboards, printers, self-checkout machines, cell phones, and the ever-present music seeping out of teenagers' headphones. There is activity, vitality, and a sense of energy. The atmosphere is more like that of a shopping mall than a museum. Interestingly, this environment is true no matter which branch of my public library I enter. Whether at the downtown branch that serves primarily inner-city residents, or at a brand-new suburban branch, the excitement of the library is the same.

Even my academic library, which is currently undergoing a $\$ 100$ million expansion (see www.maddenlibrary.org for details), retains that same atmosphere. Although some of our users may be forced to come in because of homework assignments, most are here because they see the library as a destination of choice on campus. They use the computers; read the magazines and newspapers; check out and return books; write, revise, and edit papers; and generally hang out with each other. Students interact with other students, faculty, and library staff. Our space may be small, but our users continue to take advantage of it as much as possible.

volume 47, issue 2 | 111 


\section{FROM THE PRESIDENT OF RUSA}

My guess is that this is exactly the type of image that you see at your library.

As with Mark Twain's death, the demise of the library has been greatly exaggerated. Much has been written about "library as place." Those who predict the coming irrelevancy of the library have focused on only one of its key functions. They see the role of the library primarily as a source of information, which is only one of many activities that take place there. With the proliferation of alternative information sources (especially the Internet), our users are able to retrieve factual information on their own much more easily than at any time in human history. If the sole-or even primary-purpose of the library were to be a source of factual information, its future would, indeed, be rather limited.

However, most people use the library for many reasons other than to find factual information. My previous column ("Are You Smarter Than a Fifth Grader?" RUSQ 47, no. 1: 8-9) addressed the role of the reference librarian. Reference librarians are not—nor were we ever—simple answering machines. While we do get the odd factual question, most of the time we are engaged with our users in much more complex interactions. Reference statistics are down not because we are doing less to assist our users, but because we historically measured that assistance based on what was the easiest to count. We need to develop new ways to measure our value that reflects the complexity of our roles.

Those roles continue to change and evolve. Frequently, there is a cry within the field of librarianship that libraries and librarians must take such-and-such an action in order to remain relevant and survive. Some of the more recent statements that I have seen say that we must get involved with Second Life, that that we must be in MySpace, that we must be more like Amazon.com, or that we need to be more like Starbucks. All of these are well-intentioned calls to be innovative and make change.

My gut reaction to these statements is often based on two emotions-resentment and fear. Resentment because

\section{THAT THING WE DO}

As RUSA president, I have the privilege of contributing a short piece to each quarterly issue of RUSQ during my presidential term. While there is a lot to be said (and I certainly have never been accused of being at a lack of things to say), my four columns are intended to provide a perspective on my presidential theme. The first in the series, "Are You Smarter Than a Fifth Grader?" discussed the misconception of reference librarians as answer machines. This column continues that process by focusing on some of the external demands being placed on libraries and reference services. The next column will focus on the main theme. Although I am not giving any hints as to what that might be, you can be sure that it will be a quality piece.
I don't like other people telling me what I have to do, and fear because they just might be right. The more impassioned the advocate for the must-do activity, the more emotional is my response. A few authors are talking about getting rid of the reference desk, which draws out my National Rifle Assocation-inspired reactionary answer: "when they pry my cold dead fingers off of it." Obviously, this response does not lead to constructive and positive dialogue. We need to move past this and base our responses on the intellectual concepts rather than the emotional baggage.

The biggest problem with any of these must-do's is that they imply that all libraries have to take the same approach to whichever problem is presented. Although libraries do have many similarities, each was established to serve a specific community. The success of any library is not measured by how it follows trends in the profession, but by how it serves the members of its parent community. To paraphrase Tip O'Neill, all librarianship is local. Each of us needs to evaluate these must-do's in terms of how they would benefit our own communities. Some will and some will not. We need to step back, look at how each idea would work in our local community, and apply it or not. The bandwagon usually will keep rolling, but we do not all have to get on it.

One of the very positive must-do's of recent times is the Web 2.0 movement. Although I do not attempt to understand the specifics of the technology behind Web 2.0 (Ajax and SOAP are still household cleaners in my life), I think that its social goals correlate directly with our profession. While there are as many definitions of Web 2.0 as there are practitioners, three common characteristics that are usually included in Web 2.0 are personalization, interactivity, and social networking. All of these concepts are relevant in libraries as well.

Personalization is the idea of giving the users what they want from the system. The user can define which features are used or not used, can set specific options on and off, and get personalized feedback. Amazon's "if you bought this, you will like this" feature often is touted as a prime example of personalization. Libraries have been involved with personalization since, well, the invention of the library card. All library users have their own accounts, can use any or all parts of the library with that account, and can suggest additional materials for the collections. We have delivered materials to users for years, using technology ranging from the postal service to bookmobiles to fax machines to the Internet. Readers' advisory is one of the oldest reference services in our profession. One librarian, Nancy Pearl, even became an action figure by doing in person what Web 2.0 is doing online. When our users recommend resources to us, we usually purchase them. Libraries have been personalizing their resources ever since the Boston Public Library opened its doors in 1854.

Interactivity is another design feature of Web 2.0. The intent is to give users a rich experience within the system, allowing them to explore on their own and providing many pathways to the end results. Users will be pleased with the experience, and that will encourage them to use it again. Libraries have been interactive ever since we opened up our 
stacks and allowed browsing. Our users are able to explore our resources at their own pace and in their own style. As technology changed, libraries added music listening stations, video players, and computers connected to databases and the Internet. In addition to the collections, users are able to interact directly with staff. Reference service is indeed the "Personal Relations Between Librarians and Readers" that Samuel Green discussed almost 150 years ago. ${ }^{1}$ The addition of telephone, e-mail, and virtual reference channels have extended this interaction beyond the library walls.

Social networking is touted as one of the biggest benefits of Web 2.0. Through such services as MySpace, Facebook, and Second Life, people are able to use technology to interact not just with software, but with other people. This brings me back to the experiment that begins this column. Assuming that your library is a lively place, that energy that you see around you is the library version of social networking. People come to the library for many things, but one of the most important is the ability to interact with other people. As more and more institutions in our society are being designed to minimize human contact (think automated phone systems, gas stations, and online shopping), the library's social aspects become even more important. A few people come to us for factual information. Many more come for entertainment purposes (leisure reading, videos, audios, and computers). More and more are coming because the library is a social center, with programs, materials, and staff that enhance human contact.
Web 2.0 is good not because it makes the library more like the Web, but because it is making the Web more like the library. By my calculation, we are on Library 4.0 (see sidebar on this page), so the Web has a way to go to equal the services of the library. However, libraries have been around for millennia, and the Web for fifteen years, so it will catch up quickly.

This brings us back to the function of the reference librarian (this is a reference journal, after all). For almost 150 years, we reference librarians have served to enhance the interactive nature of the library. We answer questions, suggest reading materials, advise on research strategy, teach about our resources, schedule programs and events, help with equipment, direct people to the bathrooms, and interact in hundreds of other ways with the people who form our community. The reference librarian is the library's human face and a gateway to an entire social network of library users. Our functions and tools have continued to evolve as our community needs have changed. Amid all the hype and the changes, the important factor to remember is that we serve our community's needs. Helping and guiding and interacting with users— that thing that we do-will do as much to keep the library relevant and vital as any new technology or program.

\section{Reference}

1. Samuel Swett Green, "Personal Relations between Librarians and Readers," Library Journal 1 (Oct. 1876): 74-81.

\section{LIBRARY 4.0}

With all of the hype about Web 2.0, some people are promoting the concept of Library 2.0. Although the motivation behind Library 2.0 is all well and good, they don't have the numbers right. Libraries have gone through a long period of innovation and are well beyond level two. In my opinion, a numbered series of versions of the concept of Library would read as follows. (And as with any good upgrade, each version of library incorporates all of the developments and features of those that came beforehand.)

Library 1.0. Historically, the first function of Library was to build collections. This function dates back to ancient times and continues with us today. During version one, libraries focused entirely on materials.

Library 2.0. The second version of Library is the one that focused on organization. This version began some time around the sixteenth century and continues to be a part of all later versions. During this era, we developed organizational schema to make our collections easier to use. Cataloging, indexing, and metadata are all modern remnants of Library 2.0.
Library 3.0. The third edition of Library is the one that focuses on service. Beginning in the mid-nineteenth century, libraries began to provide direct personal assistance to users. This is the version of the Library that spawned the reference desk, instruction, readers' advisory, and even this journal.

Library 4.0. We are currently in transition from Library 3.0 to Library 4.0. I would characterize Library 4.0 as the era in which the library serves not merely as the collector and organizer of information, but also as the producer or publisher of information. Modern technologies, such as digitization and telecommunications, allow us to distribute material that is unique to our institution, making it available to the rest of the world. Exactly how this will affect the traditional publishing industry is not yet known, but version 4.0 should look very different in the future than today's version 3.0.

There will, no doubt, someday be a Library 5.0. What will make 5.0 unique is something that future generations will need to define. For now, let's stop looking into the past by calling it Library 2.0, and begin looking at the present by calling it Library 4.0. 